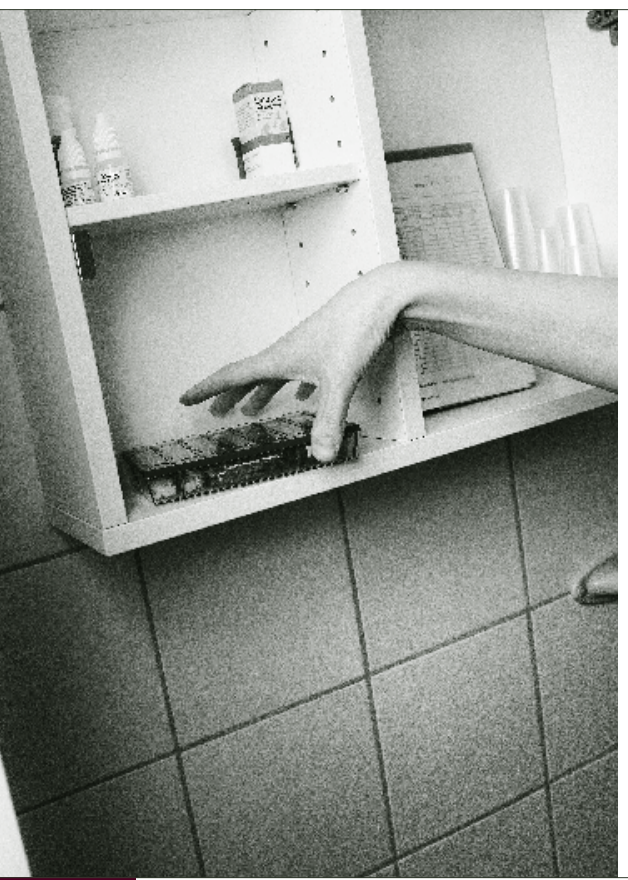

Bakgrunn: For å sikre sykehjemspasienter effektiv og forsvarlig legemiddelbehandling, kreves hensiktsmessige rutiner for forskrivning, håndtering og effektdokumentasjon både av legemidler gitt fast og ved behov. Vår kunnskap om forholdene rundt behovsmedisinering er begrenset.

Hensikt: Få kunnskap om behovsmedisinering ved å kartlegge forskrivning og utlevering av behovslegemidler ved ett utvalgt sykehjem, samt unders $\emptyset$ ke hvor ofte og hvordan effekten av gitte behovslegemidler ble dokumentert.

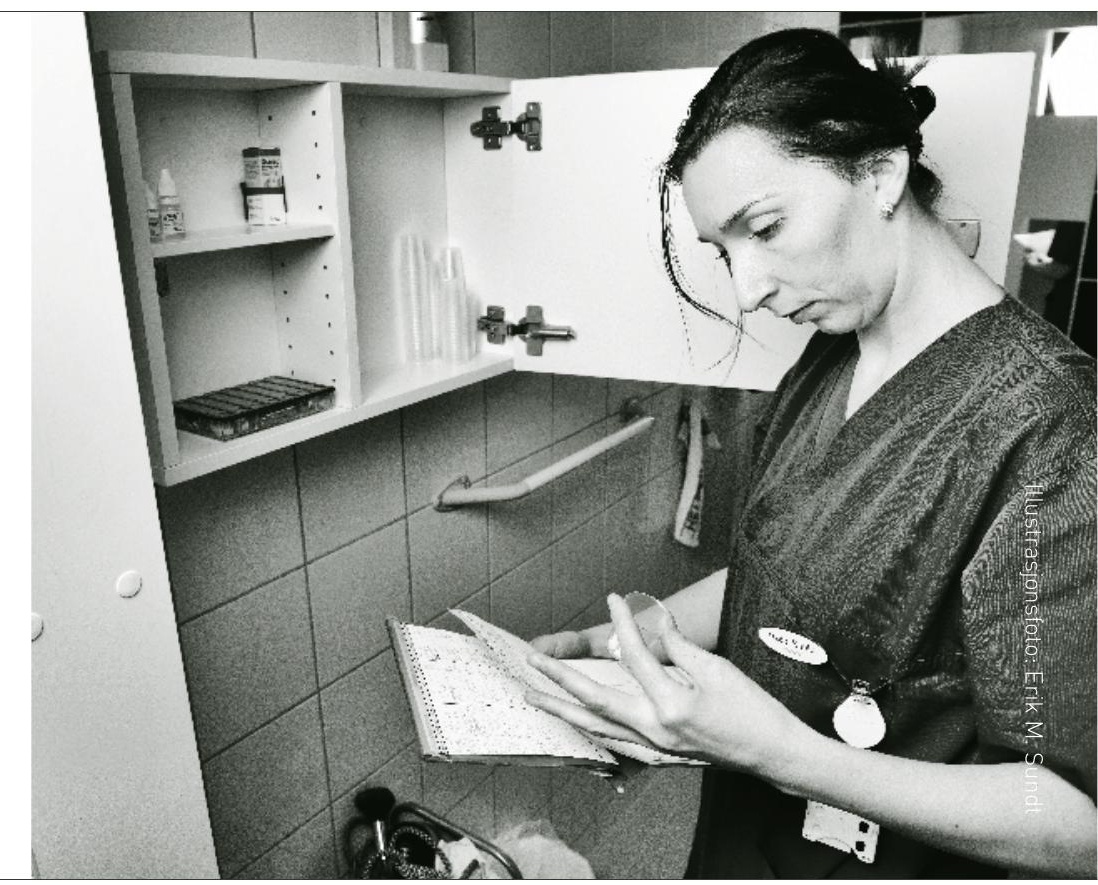

Metode: Vi unders $\varnothing$ kte 15 ukers-prevalensen av foreskrevne og utleverte behovslegemidler, samt dokumentasjon av effekt for disse gjennom innsamling av data fra legemiddelkort, elektronisk pasientjournal og kvitteringsark fra 108 pasienter ved ett sykehjem i Bergen. Deskriptive analyser ble utført i SPSS.

Resultater: Pasientene fikk i gjennomsnitt forskrevet fire behovslegemidler hver i løpet av studieperioden. To av tre foreskrevne legemidler ble imidlertid aldri gitt til pasientene mens studien pågikk. Dokumentasjon av effekt for utleverte behovslegemidler var mangelfull, både når det gjaldt kvantitet og kvalitet. Effekten ble dokumentert i 1/3 av tilfellene.

Konklusjon: Det er behov for hyppigere gjennomgang av legemiddelkortene med tanke på å endre, seponere eller forskrive behovslegemidler slik at ordinasjonene bedre gjenspeiler pasientenes faktiske behov. God effektdokumentasjon er en forutsetning for å kunne «skreddersy» legemiddelbehandlingen.
Medication Needs in Nursing Homes: Prescribing, Use and Documentation of Effect

Background: To ensure safe and appropriate use of medicine at all hours for nursing home patients, good routines for prescribing handling and documentation of effects for P.R.N. medication must be established. We have little knowledge of how this is practiced today.

Objective: To document prescription and administration of P.R.N. medication in one nursing home, and to investigate how often, and how, the effects of P.R.N. medication are documented
Method: We investigated the prevalence of prescribed and administered P.R.N. medications during 15 weeks, and observed the documentation of effects for these medications by collecting information from drug charts, the electronic patient record and medication administration records for 108 patients in one nursing home in Bergen, Norway. We used SPSS to analyse the collected data (descriptive statistics).

Results: Within the study period each patient had on average four different of P.R.N. medications prescribed on their drug chart. Two thirds of the prescribed P.R.N. medication was never administered to the patients during the 15 weeks.
The documentation of effects for the administered P.R.N. medication was inadequate, both regarding quantity and quality. The drug effects were documented in 1/3 of the cases.

Conclusion: There is a need for more regular review of the prescribed medication to change, stop or add P.R.N. medication so that the drug charts reflect the actual needs of the patients. Improved documentation of the effects of administered medication is a prerequisite for safe and tailormade drug treatment.

Key Words: Medicine management, Quality, Nursing home, P.R.N. medication, Documentation. 


\section{BEHOVSMEDISINERING I SYKEHJEM:}

\section{»Forskrivning, bruk og dokumentasjon av effekt}

Forfattere: Stine Wang Rønningen, Kjersti Bakken, Anne Gerd Granås

\section{NøKKELORD}

- Medisinhåndtering

- Kvalitet

- Sykehjem

- Legemidler

- Dokumentasjon

\section{BAKGRUNN}

Legemidler er en viktig innsatsfaktor i helsevesenet, og den stadig voksende gruppen av eldre står for størstedelen av legemiddelbruken (1). I de fleste vestlige land defineres gruppen eldre som personer som er 65 år eller eldre (2). I 2011 fikk ni av ti eldre her i landet ett eller flere legemidler på resept, og 57 prosent av de eldre legemiddelbrukerne fikk utlevert flere enn fem ulike legemidler (1). Samme år ble det omsatt legemidler for nærmere 19 milliarder kroner. Økende legemiddelbruk medfører ikke bare kostnader, men også uheldige hendelser som kan gi ekstra liggedøgn på sykehus, føre til skade på pasient og i verste tilfelle død (3). Det er derfor av stor betydning at legemiddelbehandling og -håndtering foregår på best mulig måte. Først og fremst av hensyn til pasientene det gjelder, men også for samfunnet som helhet. En særlig utsatt gruppe er eldre på sykehjem. Her finner vi de sykeste eldre og omfattende legemiddelbruk. Tilstrekkelig kompetanse hos de ansatte til å håndtere legemidler og delta i legemiddelbehandling av pasient er en viktig forutsetning for pasientsikkerheten. Flere studier har i senere tid fokusert på legemiddelbehandling i sykehjem. Disse viser at gjennomsnittspasienten får forskrevet fra fem til 11,5 legemidler, avhengig av om både faste og behovslegemidler er inkludert og hvilken metode som er benyttet (4-7). Samtidig bruk av flere legemidler, såkalt polyfarmasi, øker risikoen for legemiddelrelaterte problemer (LRP), og tre av fire sykehjemspasienter har minst ett legemiddelrelatert problem (6). LRP defineres som «hendelser eller forhold som skjer i forbindelse med legemiddelbehandling og som faktisk eller potensielt interfererer med ønsket helseeffekt» $(8,9)$. De fleste studier gjort på dette feltet tar imidlertid for seg pasientenes faste legemidler, legemidler pasienten skal ta til forhåndsbestemte tidspunkter. Få studier har sett nærmere på forskrivning og reell bruk av legemidler som tas ved behov (også kalt «eventueltmedisin») (10-13). Behovsmedisinering representerer flere utfordringer for helsepersonell i sykehjem. For det første må de som observerer pasienten ha god kjennskap til sykdommer og symptomer og tilstrekkelig legemiddelkunnskap. Det kan dessuten forekomme forskrivninger av flere ulike behovslegemidler med samme indikasjon på legemiddelkortene og de generelle skriftlige direktivene, samt uklar informasjon om dose og styrke (13). Dette legger et stort ansvar på sykepleier som tar beslutninger knyttet til utlevering. Samtidig bør pleierne kjenne pasientene godt for å kunne tolke pasientenes reelle behov, noe som kan være særlig utfordrende ved demens. Behovslegemidler deles

\section{Mer om forfatterne:}

Stine Wang Rønningen har master i farmasi fra UiB og er ansatt ved Boots apotek, Kolbotn. Kjersti Bakken er førsteamanuensis ved institutt for samfunnsmedisin, Universitetet i Troms $\varnothing$. Anne Gerd Granås er førsteamanuensis ved institutt for farmasi og bioingeniørfag. Høgskolen i Oslo og Akershus. Kontakt: stiwarolahotmail.com.

\section{Hva tilfører artikkelen?}

Artikkelforfatterne fant at dokumentasjonen av effekt av behovsmedisineringen ved sykehjemmet, der unders $\varnothing$ kelsen ble gjennomført, var mangelfull både når det gjaldt kvantitet og kvalitet. 
ut til alle tider på døgnet, og da vil bemanning og kompetanse hos dem som er på jobb ha stor betydning for beslutningstaking om å gi behovslegemidler, for utlevering og for observasjon av effekt hos pasientene etter inntak. Ofte er mange personer involvert i behovsmedisineringen; legen som har forskrevet legemidlet på legemiddelkortet eller i generelle skriftlige direktiv, helsefagarbeideren som observerer behovet for ekstra medisinering hos pasienten, blir gitt har tiltenkt effekt eller ikke. Hvem som skal gjøre dette, eller hvordan, er ikke spesifisert ytterligere. Vi har ikke funnet forskning som omtaler effektdokumentasjon av behovslegemidler på sykehjem. Helsetilsynet har imidlertid gjennom flere tilsynsrapporter påpekt mangelfull journalføring av legemiddelbehandling, uvisshet om hvordan legemidlers virkninger og bivirkninger skal dokumenteres, samt uklarheter om hvor man kan finne viktige opplysninger i kom-

\section{En klar og entydig forskrivning må danne utgangspunktet for all legemiddelbehandling.}

sykepleieren som tar beslutningene rundt utlevering, og helsefagarbeider eller sykepleier som deler ut legemidlet og i etterkant skal observere effekten av legemidlet. Vaktskifter kan bidra til enda flere involverte. Nødvendigheten av behovsmedisin til den enkelte pasient bør vurderes fortløpende av legen i samarbeid med sykepleier. Sykepleier skal vurdere når utdeling kan skje, og personell med fullmakt kan forestå utdelingen etter først å ha konferert med sykepleier. Det skal kvitteres på eget skjema ved utlevering av behovsmedisin, og effekten skal registreres (14).

God skriftlig og muntlig kommunikasjon er av stor betydning ved de fleste aspekter av pasientbehandling. En klar og entydig forskrivning må danne utgangspunktet for all legemiddelbehandling. Entydig dokumentasjon av utdelte legemidler, og effekten av disse hos den enkelte pasient, er også viktig. Dette gjelder ikke minst ved behovsmedisinering. For å sikre effektiv og individuelt tilpasset legemiddelbehandling må behandlingsapparatet få tilbakemelding på om legemidlene som binerte elektroniske og papirbaserte journaler (15). «Riktig legemiddelbruk i sykehjem» er da også valgt som ett av innsatsområdene i den pågående pasientsikkerhetskampanjen «I trygge hender» (16). Hensikten med vår studie var å få kunnskap om forhold rundt behovsmedisinering, ved å kartlegge forskrivning og utlevering av behovslegemidler ved ett utvalgt sykehjem, samt undersøke hvor ofte og hvordan effekten av behovslegemidlene blir dokumentert.

\section{MATERIALE OG METODE}

Vi har foretatt en kartlegging av forskrivning og bruk av behovslegemidler, samt dokumentasjonen av disse legemidlenes effekter hos pasientene ved ett sykehjem. Vi benyttet pasientdata fra Løvåsen undervisningssykehjem i Bergen. Sykehjemmet ble valgt av Bergen kommune i samarbeid med sykehjemsledelsen. Vi inkluderte journaldata fra 108 av totalt 125 inneliggende pasienter. 17 pasienter ble ekskludert da disse enten hadde vært på sykehjemmet i mindre enn 14 dager eller innlagt på korttidsavdelinger $(\mathrm{n}=8)$, eller ikke hadde fått forskrevet behovslegemidler i løpet av perioden $(n=9)$.

Pasientenes journaler, i form av elektronisk pasientjournal (ved Løvåsen sykehjem brukes Geriatric Basis Dataset (GBD)) samt legemiddelkort og kvitteringsark for gitte legemidler, ble gjennomgått 15 uker tilbake i tid fra undersøkelsestidspunktet (1. oktober 2010 til 11. januar 2011). Følgende informasjon ble hentet inn: demografiske data, foreskrevne og utleverte behovslegemidler (inkludert preparatnavn, legemiddelsubstans, styrke og dose), dato og tidspunkt for foreskrevne og utleverte behovslegemidler samt dokumentasjon av effekt (det vil si hva pleiepersonellet noterte og hvor dokumentasjonen var nedtegnet). Både leger og pleiere har tilgang til å dokumentere i GBD. Nødvendige data ble lagt inn i SPSS versjon 18.0 for deskriptiv analyse. Legemidlene ble klassifisert etter ATC-systemet (17).

\section{ETIKK OG PERSONVERN}

Prosjektet var ikke fremleggingspliktig for REK, da de klassifiserte studien som et kvalitetssikringsprosjekt. Prosjektet ble meldt til Datatilsynet etter gjeldende regler og godkjent av Bergen kommune før det ble gjennomført.

\section{RESULTATER}

Til sammen 108 pasienter, hvorav 60,2 prosent var kvinner, ble inkludert $i$ analysene (tabell 1). Gjennomsnittsalderen var 84,5 år, og hver pasient hadde om lag fem diagnoser (median).

\section{Hvilke og hvor mye behovs- legemidler forskrives?}

Til de 108 pasientene var det totalt forskrevet 445 legemidler «ved behov» på legemiddelkortene, gjennomsnittlig 4,1 fore- 


\section{TABELL 1: Pasientkarakteristika}

\begin{tabular}{lllll}
\hline & $\mathrm{n}(\%)$ & $\begin{array}{l}\text { Alder, gjennomsnitt } \\
\text { (SD) }\end{array}$ & $\begin{array}{l}\text { Antall behovslegemidler, } \\
\text { gjennomsnitt (SD) }\end{array}$ & $\begin{array}{l}\text { Antall diagnoser, median (variasjons- } \\
\text { bredde) }\end{array}$ \\
Menn & $43(39,8)$ & $80,0(9,4)$ & $4,4(2,5)$ & $5(2-11)$ \\
Kvinner & $65(60,2)$ & $87,5(8,2)$ & $3,9(3,0)$ & $6(1-12)$ \\
Totalt & $108(100)$ & $84,5(9,4)$ & $4,1(2,9)$ & $5(1-12)$ \\
\hline
\end{tabular}

SD: standardavvik

TABELL 2: Hyppigst forskrevne behovslegemidler og utleveringsfrekvens

\begin{tabular}{|c|c|c|c|c|c|c|}
\hline \multirow[b]{2}{*}{ ATC-nummer } & \multirow[b]{2}{*}{$\begin{array}{l}\text { Legemiddel- } \\
\text { substans }\end{array}$} & \multirow[b]{2}{*}{ Preparatnavn } & \multicolumn{2}{|l|}{ Forskrevet } & \multicolumn{2}{|l|}{ Utlevert } \\
\hline & & & $\begin{array}{l}\text { Antall ganger } \\
\text { behovslege- } \\
\text { midlene er for- } \\
\text { skrevet, } N=445 \\
n\end{array}$ & $\begin{array}{l}\text { Andel } \\
\text { pasienter, } \\
\mathrm{N}=108 \\
\%\end{array}$ & $\begin{array}{l}\text { Antall ganger } \\
\text { behovslege- } \\
\text { midlene er } \\
\text { gitt, } N=839 \\
\mathrm{n}\end{array}$ & $\begin{array}{l}\text { Andel } \\
\text { pasient- } \\
\text { er, } \\
\mathrm{N}=108 \\
\%\end{array}$ \\
\hline N02BE01 & Paracetamol & $\begin{array}{l}\text { Paracet, Paracetamol, Pamol, } \\
\text { Panodil, Pinex }\end{array}$ & 67 & $52,8^{*}$ & 152 & 39,8 \\
\hline N05BA04 & Oksazepam & Alopam, Sobril & 46 & $38,9 *$ & 82 & 23,1 \\
\hline N05CM02 & Klometiazol & Heminevrin & 33 & $26,9^{*}$ & 75 & 13,9 \\
\hline N05BA01 & Diazepam & Valium, Stesolid, Vival & 25 & $20,4^{*}$ & 120 & 6,5 \\
\hline N02AX02 & Tramadol & Tramadol, Nobligan, Tramagetic & 23 & 21,3 & 20 & 10,2 \\
\hline N05CF01 & Zopiklon & Imovane, Zopiclone & 21 & 19,4 & 55 & 7,4 \\
\hline C01DA02 & Glyseroltrinitrat & $\begin{array}{l}\text { Nitroglycerin, Nitromex, Ni- } \\
\text { trolingual, Minitran, Nitro-dur, } \\
\text { Nitroven, Transiderm-nitro }\end{array}$ & 19 & 17,6 & 11 & 4,6 \\
\hline N02AA01 & Morfin & Dolcontin, Morfin, Morfinsulfat & 19 & $15,7^{*}$ & 54 & 4,6 \\
\hline N02AA05 & Oksykodon & $\begin{array}{l}\text { Oxycodone, OxyContin, } \\
\text { OxyNorm }\end{array}$ & 16 & $13,9 *$ & 113 & 7,4 \\
\hline A03FA01 & Metoklopramid & Afipran & 15 & 13,9 & 41 & 6,5 \\
\hline Andre & & & 161 & - & 116 & - \\
\hline
\end{tabular}

*Samme aktive substans er forskrevet flere ganger til samme pasient, i form av ulike preparatnavn eller ulike legemiddelformer, eller ved at legemidlet er startet, seponert og startet igjen i løpet av studieperioden. 
skrevne behovslegemidler per pasient $(\mathrm{SD}=2,9)$ (tabell 1 og 2). Medianen var tre behovslegemidler per pasient (variasjonsbredde 1-19). På legemiddelkortene fantes det 57 ulike legemiddelsubstanser blant behovsforskrivningene. De ti hyppigst foreskrevne substansene finnes i tabell 2. Fra tabellen ser vi at enkelte legemiddelsubstanser er forskrevet til de samme pasien-
Variasjonen var stor; fra null til hele 143 utleveringer per pasient over 15 uker.

\section{Dokumentasjon Hvor ofte?}

Det ble dokumentert effekt for 285 (34 prosent) av de totalt 839 utdelingene av behovslegemidler i perioden. I 58 tilfeller var det overlappende dokumentasjon, hvilket vil si at effekten

\section{0 prosent av de foreskrevne legemidlene ble faktisk aldri utlevert til pasientene i lopet}

\section{av de 15 ukene.}

tene flere ganger, for eksempel er paracetamol forskrevet 67 ganger til 57 pasienter. Dette betyr at samme behovslegemiddel enten er forskrevet flere ganger (startet, seponert og startet igjen) til samme pasient, eller at pasienten har fått oppført to ulike merkenavn med samme substans på legemiddelkortet, eksempelvis både Pinex ${ }^{\circledR}$ og Paracet ${ }^{\circledR}$. I enkelte tilfeller observerte vi også forskrivning av ulike legemiddelformer med samme aktive substans, for eksempel både tabletter og stikkpiller.

\section{Hvor mye behovslegemidler utleveres?}

135 (30 prosent) av de 445 behovslegemidlene som var forskrevet på legemiddelkortene ble utlevert til pasientene i løpet av perioden på 15 uker. Med andre ord ble 310 (70 prosent) av de foreskrevne behovslegemidlene aldri benyttet i løpet av studieperioden. Samlet ble det utlevert behovslegemidler 839 ganger (tabell 2). Totalt fikk 79 (73 prosent) av de 108 pasientene utlevert ett eller flere behovslegemidler i perioden, og gjennomsnittlig antall utleveringer per pasient var 7,8 (median $=2)$. ble dokumentert både i elektronisk pasientjournal og på kvitteringsarkene. Samlet sett fant vi at kvitteringsarkene ble hyppigst benyttet, 65,6 prosent av alle notater var gjort her.

\section{Hvordan?}

For å beskrive effekten pasientene fikk av behovslegemidlene benyttet personalet totalt 59 forskjellige ord og uttrykk. Disse kunne inndeles i fem ulike kategorier; god effekt, middels effekt, dårlig/ingen effekt, spesifikke beskrivelser og uviss/ tvetydig effektbeskrivelse (tabell 3). Ulike termer for "god effekt» utgjorde 71 prosent av det totale antallet utleveringer der effekten var dokumentert $(\mathrm{N}=285)$. For utleveringene der effekten var dokumentert to steder fant vi imidlertid seks tilfeller hvor betydningen av notatene ikke samsvarte mellom den elektroniske pasientjournalen og kvitteringsarkene. Mer spesifikke beskrivelser av effekt fantes i 5 prosent av utleveringene med effektdokumentasjon, ofte i forbindelse med utdeling av sovemedisin og beroligende legemidler.

For å beskrive generelt god eller generelt dårlig effekt uten flere detaljer benyttet personalet henholdsvis 13 og 12 forskjellige ord/uttrykk i hver kategori. Mange av uttrykkene er tilnærmet like med omtrent samme betydning, men er formulert ulikt. Eksempler kan være «God» og «Bra», eller «Ingen effekt» og «Lite hjelp».

Det ble oftere nedtegnet spesifikke og utfyllende beskrivelser av effekt i det elektroniske pasientjournalsystemet (GBD) sammenliknet med kvitteringsarkene, der effekten vanligvis var beskrevet med ett eller to ord, eksempelvis "God», "God effekt», «Liten», og «Ingen».

\section{DISKUSJON \\ Oppfølging av legemiddelkortene}

Et av de mest interessante funnene var at en såpass høy andel (70 prosent) av de foreskrevne legemidlene faktisk aldri ble utlevert til pasientene i løpet av de 15 ukene. Det var imidlertid stor variasjon mellom pasientene når det gjaldt antall utleveringer av behovslegemidler. Noen pasienter fikk aldri behovslegemiddel i løpet av perioden, mens én pasient fikk utlevert ulike behovslegemidler hele 143 ganger, hvilket i praksis innebærer flere ganger daglig. Samlet kan dette tyde på at legemiddelkortene revideres for sjelden. Jevnlig gjennomgang av legemiddelkortene, for å sikre at eksisterende legemiddelforskrivninger er relevante og adekvate, er nødvendig også når det gjelder behovslegemidler. Enkelte ganger må man vurdere om et behovslegemiddel i stedet bør oppføres som fast medisin. På den måten sikrer man pasienten jevnlig dosering av for eksempel smertestillende, slik at smertegjennombrudd kan unngås og medisineringen ikke blir tilfeldig og dermed mindre 
TABELL 3: Kategorisering av effektdokumentasjon

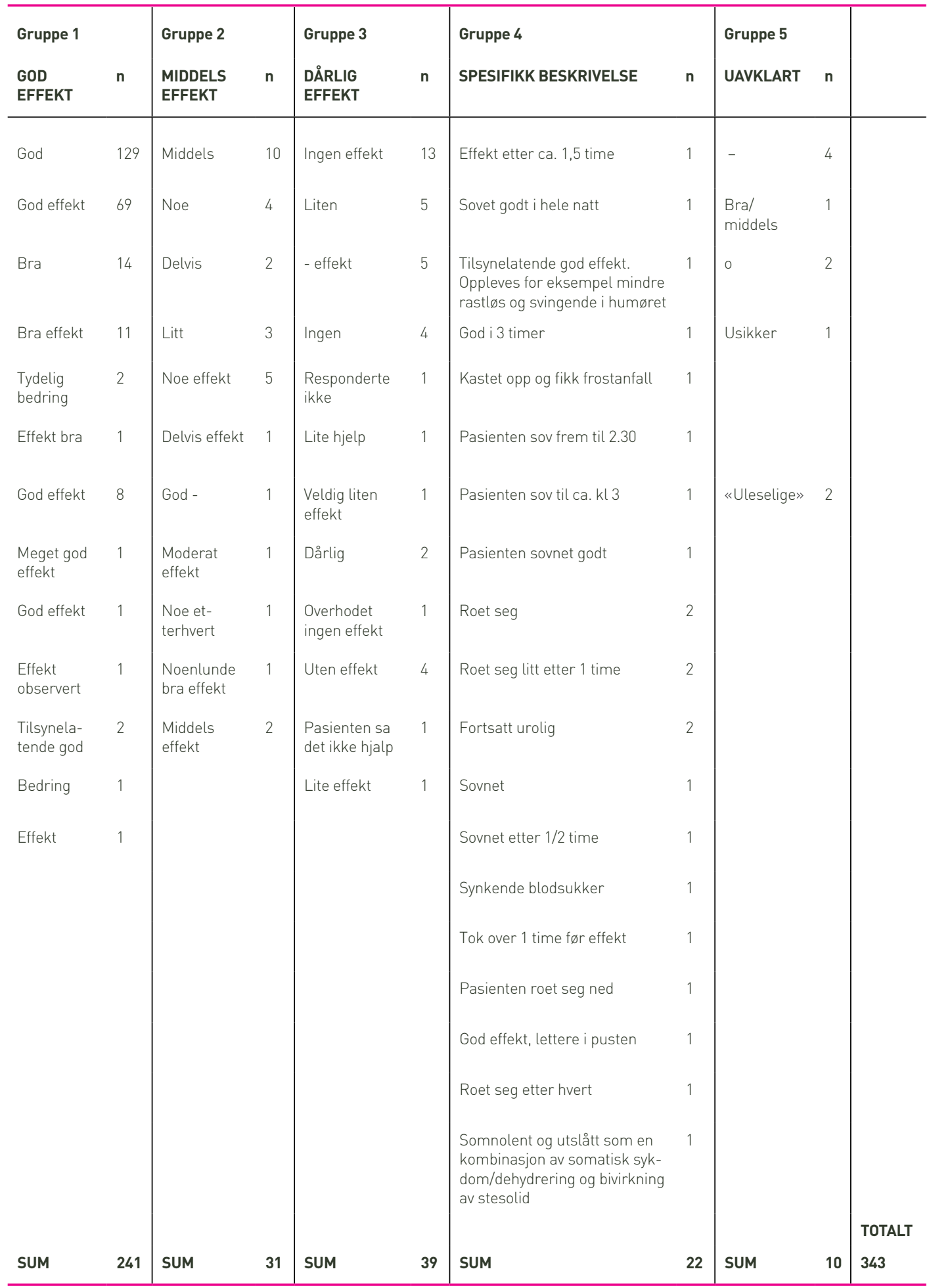


effektiv (18). Samtidig påpeker forfattere av andre artikler en tendens til at legemidler blir stående oppført på legemiddelkortene over lengre perioder, uten at de blir endret eller seponert i tråd med pasientens behov eller anbefalte retningslinjer (19-21). I mange tilfeller er det bedre at et legemiddel står oppført ved behov, for å hindre at pasienten må innta flere legemidler enn strengt nødvendig på fast basis. Et eksempel på dette kan være benzodiazepiner. At behovsle- behovslegemidler ble utlevert, var effekt ikke dokumentert. Tidligere studier har vist at mangel på tid, ansattes holdninger, ledelsens fokus på legemiddelkunnskap hos de ansatte og opplæring innen dokumentasjonsarbeid, påvirker dokumentasjonshyppighet og -kvalitet (23-26). Ved ikke å dokumentere effekten av legemidler pasienten tar, kan pasientsikkerheten trues. Mange behovslegemidler gis ved akutte behov hos pasienten, det være seg alt fra sterke smerter

\section{66 prosent av tilfellene der behovslegemid- ler ble utlevert, var effekt ikke dokumentert.}

gemidler er oppført på legemiddelkortene kan dessuten være fordelaktig, framfor at pasientene får utlevert behovslegemidler fra såkalte generelle skriftlige direktiv (13). Dette er skriftlige tilleggsprosedyrer utarbeidet på hvert sykehjem, for generell ordinasjon av enkelte legemidler når legen ikke er til stede (14). Ordinasjonene her er dermed ikke individuelt tilpasset den enkelte pasient.

Resultatene viste at de hyppigst utleverte legemidlene stort sett samsvarte med dem som var oftest forskrevet. Paracetamol var mest frekvent i bruk, etterfulgt av diazepam. At diazepam kom så høyt opp var noe overraskende, da diazepam anses som et uhensiktsmessig valg til eldre grunnet lang halveringstid og uheldige bivirkninger (22). Vi observerte imidlertid at diazepam kun ble gitt til et fătall pasienter, og det er vanskelig å avgjøre hensiktsmessighet $\mathrm{i}$ enkelttilfeller med vårt begrensete datagrunnlag.

\section{Begrensete} dokumentasjonsnotater

I 66 prosent av tilfellene der til tungpustethet eller angina. Da er det avgjørende at man vet om pasienten tidligere har respondert godt på det aktuelle legemidlet. Ved å notere effekten legger man grunnlag for nødvendige endringer i medisineringen av den enkelte pasient og dermed individualisert behandling. Fordi mange personer er involvert ved behovsmedisinering er god skriftlig kommunikasjon ekstra viktig for å ivareta pasientsikkerheten. Vaktskifter understreker ytterligere behovet for nøyaktig og oppdatert skriftlig informasjon om pasientenes respons på gitte legemidler.

\section{Hvor skal effekt dokumenteres?}

De fleste notater vedrørende legemidlenes effekt fant vi på kvitteringsarkene. Det var imidlertid interessant å se at det i 58 tilfeller ble dokumentert effekt av legemidlet både på kvitteringsarket og i det elektroniske pasientjournalsystemet. Slik dobbeltføring gjør det vanskeligere å vite hvor man kan forvente å finne den aktuelle informasjonen. Det kan også, som vi så, bety at dokumentasjonen de to stedene kan være ulik for en og samme utdeling. Det ville forenkle rutinene om dokumentasjonen konsekvent ble ført ett bestemt sted. Den største utfordringen når det gjelder dokumentasjon av effekt var likevel, at det i 66 prosent av tilfellene hvor behovslegemidler er gitt, faktisk ikke er dokumentert om legemidlet har effekt eller ei.

\section{Ustrukturert terminologi}

Den observerte effekten av behovslegemidlene ble gjengitt på svært ulike måter. Nesten 60 forskjellige ord og uttrykk ble brukt til i hovedsak å beskrive god, middels, dårlig eller ingen effekt. Det var med andre ord liten eller ingen grad av standardisering eller strukturering av innholdet i notatene. Dette kan åpne for ulike tolkninger av den beskrevne effekten av legemidlene. Mer spesifikke og detaljerte beskrivelser av legemidlenes effekter fant vi i kun 5 prosent av utleveringene av behovslegemiddel der effekten var dokumentert $(\mathrm{N}=285)$. I mange tilfeller er det nødvendig at effekten beskrives mer detaljrikt og spesifikt, for å kunne evaluere den individuelle legemiddelresponsen i ettertid. De mer spesifikke beskrivelsene fant vi oftest i den elektroniske pasientjournalen, antakelig grunnet begrenset plass på kvitteringsarkene.

\section{Hvordan forbedre dokumentasjonspraksis?}

En tysk studie fra 2007 viste at antallet pleienotater økte etter implementeringen av et elektronisk system, og at kvaliteten på dokumentasjonen økte ved tre av fire sykehusavdelinger (27). En annen studie undersøkte hvor ofte legene leste pleiejournalene, og her oppga 75 prosent av legene at de oftere leste den elektroniske journalen sammen- 
liknet med den papirbaserte (28). En av årsakene legene oppga som viktig var at lesbarheten av notatene ble bedre ved bruk av et elektronisk system. Kanskje vil et fullelektronisk system kunne øke antallet dokumentasjoner og heve kvaliteten av disse? Enkelte mener dessuten at en strukturert elektronisk pasientjournal kan være et nyttig verktøy som underletter dokumentasjonen og anvendeligheten av denne $(29,30)$. Ehrenberg og medarbeidere har konkludert med at ansatte som har fått opplæring innen strukturert dokumentasjon gjengir mer fullstendig og nøyaktig informasjon (31).

Et viktig incitament til at personalet skal dokumentere effekt er at nytteverdien oppleves som stor. Dersom ikke notatene blir brukt i ettertid, blant annet til å foreta justeringer i pasientenes legemiddelbehandling, vil motivasjonen for å notere effekt antakelig være begrenset. Første steg i riktig retning er kanskje derfor å bevisstgjøre alle involverte slik at de i større grad benytter denne verdifulle informasjonen, for eksempel ved legemiddelgjennomganger. Slike systematiske legemiddelgjennomganger fører ofte til at legemidler seponeres $(4,32)$, og den høye andelen av behovslegemidler som ikke ble gitt $\mathrm{i}$ vår studieperiode understøtter dette.

Avslutningsvis er det viktig å understreke at resultatene fra denne studien er basert på data fra ett enkelt sykehjem, som i tillegg er et undervisningssykehjem. Vi kan derfor ikke anta at funnene er representative for norske sykehjem generelt. Datagrunnlaget er begrenset, og vi har ikke hatt tilgang til karakteristika for pasientene som ble ekskludert fra studien. Løvåsen sykehjem har ekstra fokus på opplæring og forskning, de har flere fast ansatte leger og et elektronisk pasientjournalsystem (GBD) som er velegnet til blant annet oppfølging av legemiddelbehandling. Studier har vist at sykehjemskultur i seg selv kan være avgjørende for blant annet organisering og bruk av

\section{Paracetamol var mest frekvent i bruk, etter- fulgt av diazepam.}

behovsmedisinering $(10,11)$. At forhold knyttet til behovsmedisinering på Løvåsen sykehjem derfor kan være «bedre» enn ved andre sykehjem, er en rimelig antakelse. Det gir oss sånn sett grunn til å frykte at rutiner for behovsmedisinering kan være dårligere i andre sykehjem. Det er rom for forbedring knyttet til behovsmedisineringen i sykehjem. Våre resultater indikerer at forholdene, slik de er i dag, kan føre til at pasientene ikke får en tilpasset legemiddelbehandling og oppfølging av behovsmedisineringen på en adekvat måte. Behovslegemidler skal benyttes ved akutte behov hos pasientene, og det er av stor betydning at de får riktig medisin, i riktig dose, til rett tid. Dette kan man oppnå ved å kontinuerlig oppfølge pasientenes behovslegemidler basert på blant annet observasjon av legemidlenes effekt. I tråd med den pågående pasientsikkerhetskampanjen vil dette være et steg i riktig retning mot bedre legemiddelbruk i sykehjem, og det er videre behov for flere og større studier på dette området.

\section{KONKLUSJON}

Studien viser at det er behov for jevnlig gjennomgang og eventuell revidering av foreskrevne behovslegemidler til pasienter på sykehjem for å sikre pasientene rasjonell og individuelt tilpasset legemiddelbehandling. Vi fant at dokumentasjonen av effekt av behovsmedisineringen var mangelfull, både når det gjaldt kvantitet og kvalitet. God journalføring av effekt er med på å legge grunnlaget for en bedre legemiddelbehandling av pasientene.

Takk til Løvåsen sykehjem, Sjukehusapoteka Vest og Eli Tverborgvik for godt samarbeid, og til Kjell Krüger og Magne Rekdal for god faglig og praktisk hjelp under datainnsamlingen.

\section{REFERANSER:}

1. Folkehelseinstituttet. Legemiddelstatistikk 2012:2. Reseptregistret 2007-2011.

2. WHO. Definition of an older or elderly person. Tilgjengelig fra: http://www.who. int/healthinfo/survey/ageingdefnolder/ en/. (Nedlastet 03.11.2012.)

3. Hjort PF. Uheldige hendelser i helsetjenesten: en lære-, tenke- og faktabok. Gyldendal akademisk, Oslo. 2007

4. Halvorsen KH, Ruths S, Granås AG, Viktil KK. Multidisciplinary intervention to identify and resolve drug-related problems in Norwegian nursing homes. Scand J Prim Health Care. 2010;28:82-8. 5. Rytter E, Nakken KO, Mørch-Reiersen LT, Efjestad A, Selvig K. Bruk av antiepileptika hos sykehjemsbeboere. Tidsskr Nor Lægeforen. 2007;127:1185-7.

6. Ruths S, Straand J, Nygaard HA. Multidisciplinary medication review in nursing home residents: what are the most significant drug-related problems? The Bergen District Nursing Home (BEDNURS) study. Qual Saf Health Care. 2003;12:176-80

7. Kirkevold $\emptyset$, Engedal K. Is Covert Medication in Norwegian Nursing Homes Still a Problem?: A Cross-Sectional Study. Drug Aging. 2009;26:333-44.

8. Pharmaceutical Care Network Europe. PCNE Classification for Drug Related Problems V6.2. Tilgjengelig fra: http://www.pcne.org/sig/drp/documents/drp/PCNE\%20classification\%20 V6-2.pdf. (Nedlastet 06.10.2010)

9. Ruths S, Viktil KK, Blix HS. Klassifisering av legemiddelrelaterte problemer. Tidsskr Nor Lægeforen. 2007;127:30736.

10. Stokes JA, Purdie DM, Roberts MS. 
Factors influencing PRN medication use in nursing homes. Pharm World Sci. 2004:26:148-54

11. Roberts MS, King M, Stokes JA, Lynne TA, Bonner CJ, McCarthy S, et al. Medication prescribing and administration in nursing homes. Age Ageing. 1998;27:385-92.

12. Curtis J, Capp K. Administration of 'as needed' psychotropic medication: A retrospective study. Int J Ment Health Nurs. 2003:12:229-34.

13. Andreassen LM, Halvorsen KH, Granås AG. Store ulikskapar i innhold utforming og kvalitet på dei generelle skriftlige skriftlege direktivene. Sykepleien forskning. 2011;6:46-52.

14. Bergen kommune. Retningslinjer for legemiddelhåndtering i institusjon i Bergen kommune. Versjon 2.1. Bergen 2010. 15. Helsetilsynet. Sårbare pasienter utrygg tilrettelegging Tilgjengelig fra: http://www.helsetilsynet.no/upload/ Publikasjoner/rapporter2010/helsetilsynetrapport7_2010.pdf. (Nedlastet 16.01.2011]

16. Nasjonal enhet for pasientsikkerhet. Pasientsikkerhetskampanjen I trygge hender 2011-2013. Tilgjengelig fra: http://www. pasientsikkerhetskampanjen.no/. (Nedlastet 08.05.2012)

17. WHO. The Anatomical Therapeutic Chemical Classification System with Defined Daily Doses (ATC/DDD). Tilgjengelig fra: http://www.who.int/classifica- tions/atcddd/en/. (Nedlastet 26.05.2012) 18. Lellan KM. A chart audit reviewing the prescription and administration trends of analgesia and the documentation of pain, after surgery. J Adv Nurs. 1997;26:345-50.

19. Nygaard HA. Varighet av legemiddelbruk i sykehjem. Tidsskr Nor Lægeforen. 2001;121:1469-72.

20. Avorn J, Gurwitz JH. Drug Use in the Nursing Home. Ann Intern Med. 1995;123:195-204.

21. Ruths S, Straand J, Nygaard HA. Psychotropic drug use in nursing homes diagnostic indications and variations between institutions. Eur J Clin Pharmacol. 2001;57:523-8.

22. Ruths S, Straand J. Legemidler og eldre. I: Norsk Legemiddelhåndbok for helsepersonell. Foreningen for utgivelse av Norsk legemiddelhåndbok, Oslo. 2010. (s. 1785-90).

23. Sjöberg I, Öhman C. Faktorer som påverkar sjuksköterskors omvårdnadsdokumentation: Luleå tekniska Universitet; 2009.

24. Törnvall EVA, Wahren LK, Wilhelmsson S. Impact of primary care management on nursing documentation. J Nurs Manage. 2007;15:634-42.

25. Hansebo G, Kihlgren M, Ljunggren G. Review of nursing documentation in nursing home wards-changes after intervention for individualized care. J Adv Nurs. 1999;29:1462-73.
26. Björvell C, Wredling R, ThorellEkstrand I. Long-term increase in quality of nursing documentation: effects of a comprehensive intervention. Scand J Caring Sci. 2002;16:34-42.

27. Mahler $C$, Ammenwerth $E$, Wagner A, Tautz A, Happek T, Hoppe B, et al. Effects of a computer-based nursing documentation system on the quality of nursing documentation. J Med Syst. 2007;31:274-82.

28. Ammenwerth E, Eichstadter R, Haux R, Pohl U, Rebel S, Ziegler S. A randomized evaluation of a computer-based nursing documentation system. Methods Inf Med. 2001;40:61-8.

29. Krüger K. Elektroniske pasientjournaler bør være strukturerte. Tidsskr Nor Lægeforen. 2007;127:2090-3.

30. Sahlstedt S, Adolfsson H, Ehnfors M, Kallstrom B. Nursing process documentation - effects on workload and quality when using a computer program and a key word model for nursing documentation. Stud Health Technol Inform. 1997:46:330-6.

31. Ehrenberg A, Ehnfors M. The accuracy of patient records in Swedish nursing homes: congruence of record content and nurses and patients' descriptions. Scand J Caring Sci. 2001;15:303-10.

32. Kersten H, Ruths S, Wyller TB. Farmakoterapi i sykehjem. Tidsskr Nor Lægeforen. 2009;129:1732-5. 